\title{
Research on the Path of Low-Carbon Sponge City Construction from the Perspective of Carbon-Water Coupling: Taking River Chief System as the Breakthrough Point
}

\author{
Shao-xuan ZHENG ${ }^{1, a}$, Xin-nan CHEN $^{1}$,

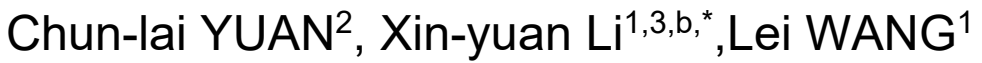 \\ ${ }^{1}$ School of Business Administration, Hohai University, Changzhou 213022, China
}

${ }^{2}$ School of economics and management, China University of Geosciences, Wuhan 430074, China

${ }^{3}$ Study and Research Group of The thought of socialism with Chinese characteristics in the new er a, Hohai University, Changzhou 213022, China

a18360831160@163.com, bhhujmd@126.com

${ }^{*}$ Corresponding author

Keywords: Low-Carbon Sponge City, River Chief System, Carbon-Water Coupling.

\begin{abstract}
Taking the relations between urban water system and carbon system into consideration and making researches on the design link can dramatically cut the costs of urban duplication construction, improve efficiency on urban ecological civilization construction, enhance urban carbon and water environment and better people's living standards. In addition, it implements the five developing philosophies, Innovation, Coordination, Greenness, Opening, Sharing, and meets the requirements of constructing the "Wild China". Take the river chief system as the breakthrough point to explore the construction path of low-carbon sponge city. It is found that both the low-carbon sponge city or the river chief system, the ultimate goal is to maximize the concentration and use of limited water resources under the constraints of multiple factors, seek the best way to manage water resources, and further optimize the water ecological environment. The construction of the sponge town is guaranteed by the river chief system, while the low-carbon sponge city construction concept enriches the implementation content and objectives of the river system. Finally, it puts forward the specific path of building a low-carbon sponge city under the system of river length, such as improving the system construction, achieving the goal by layer by layer, narrowing the differences between urban and rural areas, and promoting the coupling of carbon and water.
\end{abstract}

\section{The birth of low-carbon sponge city}

President xi revealed in the report delivered at the 19th National Congress of the Communist Party of China that we are at the decisive period of building a well-off society in an all-round way. As the development of national economy and urbanization, many problems concerning energy waste and population are emerging. Under such environmental pressure, the Party raised suggestions which have taken climate change into consideration in the "thirteen five--year plan", including rural and urban planning, infrastructure construction and production distribution. At home, new requirements of building smart, low-carbon and sponge city have also been paid great attention. However, due to the limitation of resources and experience, how to solve problems on city carbon emission and water at the same time and how to integrate carbon emission reduction action framework into the construction of sponge city while getting benefits from it directly are brand new topics which are worth careful thinking. As the constant development of society, people's focuses on urban ecology have been improved so that the researches, including its concepts, mechanism, designs and case analysis, on low-carbon and sponge city become mature. However, researches on low-carbon city and on sponge city are separated parts within china, which ignore the interrelations between urban carbon system and water system. Scholars Danjie Wu had proposed that the construction of sponge city is not only coincided with the theory of low-carbon city but also inseparably interconnected with 
it. low-carbon city and sponge city both are the concrete ways of urban development. Therefore, there is no doubt that effectively dealing with carbon and water issues and more efficiently building lowcarbon, water-saving and environment-friendly city are significant to sustainable development of cities, based on which, the research will define "low-carbon sponge city" as a environment-friendly and sustainable development pattern which can realize the dynamic equivalence between carbon emission and processing and water reserve and release without intervening the development of economic society. It will also look into the interconnection between urban carbon and water system, designing accessible developing plan for "low-carbon sponge city". Taking the relations between urban water system and carbon system into consideration and making researches on the design link can dramatically cut the costs of urban duplication construction, improve efficiency on urban ecological civilization construction, enhance urban carbon and water environment and better people's living standards. In addition, it implements the five developing philosophies, Innovation, Coordination, Greenness, Opening, Sharing, and meets the requirements of constructing the "Wild China".

\section{Ways designing on the basis of river chief system}

\subsection{Improving current system}

Under the river chief system, every watercourse at all levels will have a chief to shoulder responsibility. During the construction of low-carbon sponge city, it is indispensable to get involved in issues on watercourses and waters. As for solving relative problems, asking help of particular departments and advice from professionals is effective. However, there is a demand of management and skillful people to ensure the system working smoothly. After getting approval of upper officials, we can integrate the similar parts among river chief system and construction of low-carbon sponge city so that forming a shared management mechanism. In this way, the river chief system can make greater efforts on national development and ease troubles on low-carbon sponge city construction. Relying on current system, building up low-carbon sponge cities at higher speed and collecting labor forces, capital, resources into the innovation of low-carbon sponge city construction can realize the mutual benefits and win-win cooperation. When the working system has been built, it rises high-level requirements on cooperation if we want to ensure the efficiency, accessibility and endurance of the system, so that more emergency plans should be put up to avoid shifting the blame on one another. Once the working system meets any problem, all parties should be calm down and dealing with it properly.

\subsection{Clarifying particular problems and achieving goals step by step}

Solving problems on water safety, water resources, water environment and water ecology are goals of constructing low-carbon sponge city on the basis of river chief system. When it comes to water safety, controlling the volume of waste water through dredging all water system and watercourses at a regular period of time. Ensuring city water quality, building up rain sewage diversion system and reducing the volume of wastewater are the essential way to meet the goal. In addition, making adjustments on peak flow, forging balance among collecting, storing and releasing links, supervising every step and diving responsible scope of each party can make responsibilities to the people to be precise and orderly. As for water resources, building up rainwater reservoir according to the concrete landform of each city, enhancing cleaning function of rainwater and improving utilization of rainwater are crucial. We should also issue policies to firmly supervise water quality, safety and cleanness. In terms of water environment, it is not merely about the quality of water system, but also the surrounding environment of water system. Therefore, if we want to ensure the safety and cleanness of water system, we should pay attention to the improvement of surrounding environment. For example, before rainwater runs into rivers, we should prevent the waste water from going into rivers so as to deeply clean the water system based on the concept of sponge city. In general, we can ensure the quality of pouring-in water, not only from the beginning point but also the end part of water system, so that improving the quality of the whole water environment. For water ecology 
concern, when the requirements mentioned above have been met, it is time to build the water ecology in cities and strive a harmonious balance between people, water and nature. On the one hand, we should build green water lifeline at the same time maintain the city life axis and the "elasticity of sponge" so that all links will be smoothly operating. Furthermore, the management department of government should improve the vibrancy of water lifeline, strengthen management, clarify individual's responsibility and divide each power scope.

\subsection{Narrowing gap between the urban and the rural, achieving coordinated governance}

If we want to narrow the gap between the urban and the rural on construction of water ecological civilization, putting forward coordinated construction and development among river chief system and sponge city. As for the land utilization way, rural area is far bigger than that of urban, therefore city is just a "point" on the land while countryside is the "surface" of the land. Only through management of water resources, focusing on coordinated development on water ecological civilization between the urban and the rural and paying attention on basin coordinated governance, can we fully step into water ecological civilization.

\subsection{Strengthen the interconnection between carbon and water, enhancing developing efficiency}

The highlight of low-carbon sponge city is to integrate the low-carbon system and formation of circulating water system. Generally speaking, that is to build up the water ecology with low-carbon feature and rely on the functions of river chief system to realize high efficiency of hydroenergy development. In this way, we have the chance to adopt low-carbon life and these two policies will be more convincing among people. In the report delivered at the 19th National Congress of the Communist Party of China revealed that "we should enhance the overall design and organizational leadership of ecological civilization construction, build up management system of state-owned natural resources and supervision mechanism on natural ecology, improve management on ecological environment and make responsibilities to the people precisely and orderly", as we known, the carbon environment and water environment are two key natural resources. Every cities can integrate the constrained objective of lowing carbon emission and management goal between water resources and carbon resources, establish unified management institutions to rational use local natural resources, including energy, water, and carbon so as to realize coordinated use of different kind of resources and protect our environment effectively.

\section{Conclusion}

The river chief system and the low-carbon sponge city are bound to be an indispensable tool for the construction of modern cities and towns. This is an inevitable trend in today's "harmony between heaven and man". Without destroying the original ecosystem, building a complete set of water ecological framework is essential for the progress and development of the city. In recent years, the Party Central Committee and the state have put forward relevant policies, not only let us see the state's attitude towards the protection of ecology and ecology, but also further our expectation of the green and green landscape of the future home. A profound understanding of the outstanding problems in the process of urban construction and solutions to them is of great significance to the building of a beautiful China. We should carefully examine the rationality and shortcomings of the system, and concentrate on the management mechanism of the long system under the guiding ideology of the new concept of low-carbon sponge city. At the same time, the community and the masses should also actively participate in the construction of urban water ecology and water circulation system, so that every citizen is responsible, The beautiful and beautiful China will be in time.

\section{Acknowledgement}

This research was financially supported by the National Undergraduate Innovative Training Program(201710294098, 201710294101). 


\section{References}

[1] WU D J,ZHAN S Z, LI Y H etc. New Trends and Practical Research on the Sponge Cities with Chinese Characteristics[J]. China Soft Science,2016,(01):79-97.

[2] YU H L,ZENG J. Construction of sponge city under the perspective of adaptability[J]. Journal of Arid Land Resources and Environment,2017,(03):76-82.

[3] ZHANG W, WANG J Z, CHE H. Experience of Sponge City Master Plan: A Case Study of Nanning City[J]. City Planning Review,2016,(08):44-52.

[4] MO L,YU K J. Structure the Urban Green Sponge: Study on Planning an Ecological Stormwater Regulation System[J]. Urban Development Studies,2012, (05):130-134.

[5] YU K J, LI D H,YUAN H etc. "Sponge City": Theory and Practice[J]. City Planning Review,,2015,(06):26-36. 